\title{
Workers of the stingless bee Melipona scutellaris are more similar to males than to queens in their cuticular compounds
}

\author{
Warwick E. KERR ${ }^{a}$, Harald JUNGNICKEL ${ }^{\text {b,c }}$, E. David MORGAN ${ }^{\text {b* }}$ \\ a Instituto de Genética e Bioquímica, Universidade Federal de Uberlândia, 38400-902-Uberlândia MG, Brazil \\ ${ }^{\mathrm{b}}$ Chemical Ecology Group, Lennard-Jones Laboratory, Keele University, Staffordshire ST5 5BG, UK \\ c Present address: Department of Chemistry, UMIST, Sackville Street, Manchester M60 1QD, UK
}

(Received 16 December 2003; revised 11 March 2004; accepted 17 March 2004)

\begin{abstract}
The cuticular compounds from the wings of workers, males and queens of the stingless bee Melipona scutellaris Latreille 1811 were analysed by combined gas chromatography-mass spectrometry. This has shown that males, queens and workers have different patterns, but that the pattern of workers is much closer to that of males than it is to queens, supporting other evidence from morphology and behavior that Meliponinae workers are more similar to males than to queens.
\end{abstract}

Meliponinae / cuticular signature / polyphenism / hydrocarbons / caste

\section{INTRODUCTION}

Workers and queens of Apis mellifera L. are so similar that beginner beekeepers have difficulty in distinguishing one from the other, but males are very different from both of them. On the contrary, males and workers of meliponine bees are very similar, and difficult to differentiate. This was noted for the first time by the German emigré Fritz Müller in a letter of 12 September 1875, to Charles Darwin (quoted by Zillig, 1997). There Müller says: "In each species (of stingless bees) males and workers extraordinarily resemble each other, meanwhile both differ very much from the fertile females (virgin queens). It is a curious fact to me that both types offemales (fertile and unfertile) are so different, and that the infertile are analogous to the males, and the fertile females are more similar to fertile females of other species rather than to workers and males of its own species. Fertile female queens very likely separated much less from the common ancestor, unlike what occurred with males and workers, and this may explain the situation that fertile females very likely leave the nest only once to be inseminated, and then spend all their lives in the dark, where colours have few meaning for them".

Meliponine workers resemble males more than queens in their external morphology (Salt, 1929; Kerr, 1974, 1987; Kerr and Cunha, 1990). Melipona queens are brown and dull in nearly all species. However males and workers are handsomely coloured, and some species have yellow bands on their abdomens (Kerr, 1974, 1987). These similarities and differences between castes in stingless bees have been studied through comparisons of morphology and behaviour (Darchen, 1969; Winston and Michener, 1977).

\footnotetext{
* Corresponding author: e.d.morgan@chem.keele.ac.uk
} 
Table I. Generalized Mahalanobis distances (D) obtained from morphological data between queens, workers and males, standardized to units of 100 for comparison, among six species of Apidae.

\begin{tabular}{lccccc}
\hline & \multicolumn{4}{c}{ Generalized Distance (D) } & References \\
\cline { 2 - 6 } Species & $\begin{array}{c}\text { Queen to male } \\
\text { (A) }\end{array}$ & $\begin{array}{c}\text { Queen to worker } \\
\text { (B) }\end{array}$ & $\begin{array}{c}\text { Male to worker } \\
\text { (C) }\end{array}$ & $\begin{array}{c}\text { Ratio } \\
\text { B/C }\end{array}$ \\
\hline Bombus atratus & 100 & 83.56 & 31.34 & 2.7 & Kerr, 1987 \\
Melipona compressipes & 100 & 76.58 & 41.99 & 1.8 & Kerr et al., 1975 \\
Melipona scutellaris & 100 & 134.10 & 86.10 & 1.6 & Almeida, 1985 \\
Melipona marginata & 100 & 56.27 & 41.07 & 1.4 & Kerr et al., 1975 \\
Melipona quadrifasciata & 100 & 55.26 & 52.02 & 1.1 & Campos, 1979 \\
& Above this line, workers are closer to males & & \\
Apis mellifera & Below this line, workers are closer to queens & & \\
\hline & 100 & 59.93 & 109.06 & 0.6 & Campos, 1979 \\
\hline
\end{tabular}

Kerr (1975) proposed the hypothesis that similarity between workers and males in meliponines is under genetic control, which means that in both castes, genes responsible for similar morphology and behaviour are regulated and expressed in similar ways. Juvenile hormone was found to have an important role in caste phenotype expression in the larval stages of meliponine bees (Campos, 1975; Kerr et al., 1975; Bonetti and Kerr, 1985; Bonetti et al., 1994).

Using a program of numerical taxonomy with 45 morphological characters of the castes of Melipona quadrifasciata Lepeletier, the phenogram obtained showed that workers are more similar to males than to queens (Kerr et al., 1978). Estimation of the generalized Mahalanobis distances between queens, males and workers of six species, showed that in all investigated meliponines, workers are more closely related to males than to queens (Tab. I). Campos (1979) generalized these findings to all meliponines. For Apis mellifera the study revealed the opposite, with workers being more similar to queens than to males (Campos, 1979).

There are also behavioural similarities between males and workers in stingless bees. Within the nest, males secrete wax, like their worker counterparts (Drory, 1874, 1877, 1883). CruzLandim (1963) performed histological studies on the male wax glands and found a striking resemblance between male and worker wax gland morphology. Males are also able to work with the produced wax inside the hive, they col- lect wax, put it in wax deposits and are even capable of using it for the construction of wax pillars (Kerr, 1997).

In contrast to males and workers, the evolution of meliponine queens has been in the direction of more efficient reproductive aspects. In the majority of meliponine species studied so far, the queens are singly mated with one male, only five species are known where the queen is multiply mated with two to six males (Toth et al., 2002). Physogastric queens of Melipona compressipes fasciculata Smith have an average life expectancy of five years (unpublished observation of WEK), whereas most meliponine males and workers live for only for a few weeks.

It is becoming increasingly clear that cuticular hydrocarbons are important recognition substances in social insects as indicated by the results of many experiments (Singer, 1998; Breed, 1998). These cuticular hydrocarbons are characteristic of a group (species or colony) but may also vary within that specific group with stage of development, caste, sex or patriline (Blomquist et al., 1998; Monnin and Peeters, 1999; Sledge et al., 2001; Boomsma et al., 2003). The cuticular substances produced are a reflection of the enzymes and their activity, and these reflect the genes activated to produce them. We have examined the cuticular compounds of adult queens, males and workers of a meliponine bee, Melipona scutellaris Latreille to see if the similarities among workers and males, besides morphological and behavioural, can also be demonstrated in the 
chemical composition of the cuticle. We have indeed found such a similarity between worker and male cuticular substances.

\section{MATERIALS AND METHODS}

Melipona scutellaris bees came from the meliponary (apiary for Melipona colonies) of the Federal University of Uberlandia. This meliponary has 70 hives that came from Diamantina forest (Bahia State, $13^{\circ} \mathrm{S}, 40^{\circ} \mathrm{W}$ ). In order to avoid problems of immature individuals, care was taken to select mature, foraging workers, and males and queens had been present in the nest for some days before collection. The wings of bees contain the same pattern of cuticular substances as is found on the rest of the body, and the wings are less subject to contamination from surfaces with which the bees come into contact (Oldham et al., 1994). They can be removed with the minimum of handling and by our method of analysis (Morgan, 1990), the wings of a single individual give a sufficiently strong chromatogram and mass spectra for all the major substances to be identified.

Pairs of wings of 10 adult males, 10 workers and 5 queens of Melipona scutellaris were carefully removed with forceps and placed inside soft glass capillaries, the wings of one individual in each capillary, sealed at one end. The other end was then sealed in a small flame and sent from the meliponaries (Federal University of Uberlândia) to Keele for chemical analyses. Males were collected when flying and sitting in front of hives, at $1000 \mathrm{~h}$; workers and virgin queens were collected inside 5 hives, one of each caste from the same hive.

The wings of individual bees were analysed for their cuticular compounds by combined gas chromatography-mass spectrometry, using the Keele solidsampling method (Morgan and Wadhams, 1972; Morgan, 1990). Chromatography was carried out on a Hewlett-Packard 5890 gas chromatograph directly coupled to a 5970B Mass Selective Detector (quadrupole mass spectrometer using $70 \mathrm{eV}$ electron impact ionisation). The system was controlled and data accumulated on a Hewlett-Packard series 300 computer with HP 5970C Chemstation. Mass spectra were scanned from $\mathrm{m} / \mathrm{z} 35$ to $\mathrm{m} / \mathrm{z} 550$. Scan time was about $2.4 \mathrm{~s}$. Chromatography was performed on a immobilised polydimethylsiloxane phase in a fused silica column $(12 \mathrm{~m} \times 0.2 \mathrm{~mm}, 0.33 \mu \mathrm{m}$ film thickness) (SGE, Milton Keynes, UK). Helium was used as carrier gas at $1 \mathrm{~mL} / \mathrm{min}$. The sample in the glass capillary was heated in the injection port (temp $200{ }^{\circ} \mathrm{C}$ ) for 2 min before crushing and starting the chromatography. The oven was programmed from $30{ }^{\circ} \mathrm{C}(3 \mathrm{~min})$ at $8{ }^{\circ} \mathrm{C} / \mathrm{min}$ to $250{ }^{\circ} \mathrm{C}$. The split valve was closed before crushing the sample and reopened
30 s later. The identification of compounds was confirmed by comparison of their mass spectra and retention times with those of standards and using MS-databases.

The statistical analysis was performed using SPSS (11.0.0). For the statistical analysis the peaks of each chromatogram were taken as $100 \%$ and the percentage of each peak calculated to standardize the data set. A normal Principal Component Analysis and a Discriminant Analysis were used to show that all queen samples can be separated from all worker samples. The low Wilks' Lambda value of 0.044 indicates a good separation of the two groups by describing $95.66 \%$ of the variance. The leave-oneout method was used to prove the separation. A second Discriminant Analysis was done with all male samples as ungrouped cases. The statistical analysis should show whether the ungrouped cases ( $=$ male samples) were distributed either to the queen or worker samples, or to both of them, and therefore should show their relatedness towards the two groups.

\section{RESULTS}

Typical chromatograms of epicuticular wax from wings of workers, males and queens of $M$. scutellaris are shown in Figure 1. In all the cases examined, the cuticle contained a simple mixture of alkanes and alkenes from $\mathrm{C}_{19}$ to $\mathrm{C}_{29}$, with very small amounts of ethyl esters in males and queens, and some long-chain alkyl acetates in the queens. In workers the most abundant substances are heptacosane and heptacosene (equal quantities), followed by pentacosane (Tab. II). In males they are, in decreasing order, heptacosane, heptacosene, and pentacosane. In queens, the major substance by far is tricosane, with less than half that quantity of pentacosane.

The statistical analysis showed that all ten ungrouped data sets (= males) were grouped into the "worker" group (see Fig. 2). The results show that the cuticular wax patterns of males and workers are closely related to each other and are distinct from the pattern of the queens.

\section{DISCUSSION}

The pattern of cuticular substances was distinctive for each category of individuals, but the pattern for Melipona workers was found to be much closer to that of males and quite different from that of queens. The presence of stearyl and 

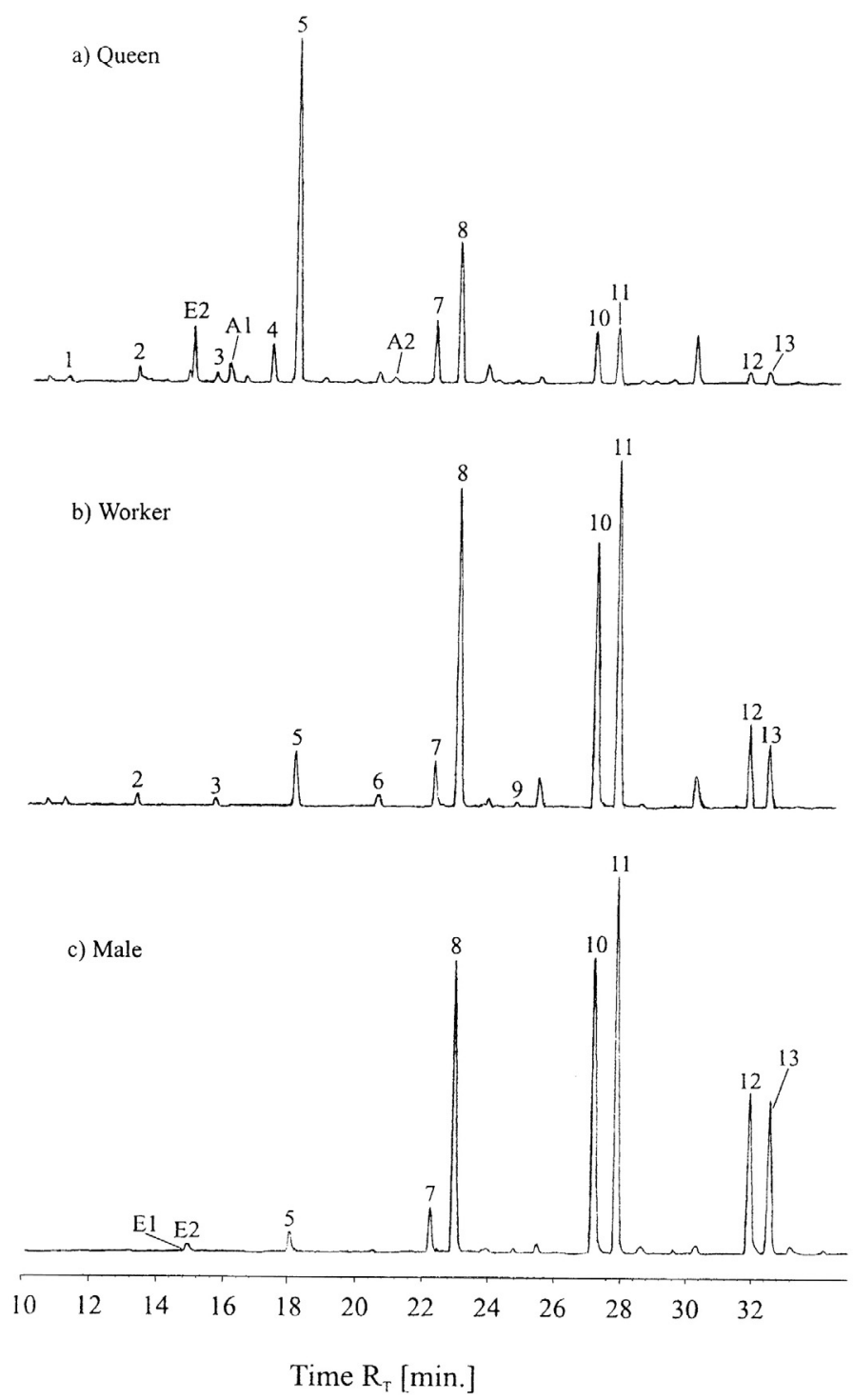

Figure 1. Cuticular profiles by gas chromatography of queens, workers and males of Melipona scutellaris. The vertical axis is detector response, which is converted to amount of compound. Each peak represents a single compound and the area under the peak is proportional to the amount of that substance. The numbers on the peaks correspond to the numbers of the compounds in Table II.

arachidyl acetates only in queens may be worthy of further examination.

The chemical analyses of the cuticle of all three categories of the stingless bee Melipona scutellaris provided another and surprising demonstration that workers are more similar to the males than to the queens in meliponine bees. Tricosane was the major component in the queens of M. scutellaris, while heptacosene and heptacosane were the major components in workers and males, making them distinct from queens.

In Apis mellifera Francis et al. (1989) found that the predominant substances of newly 


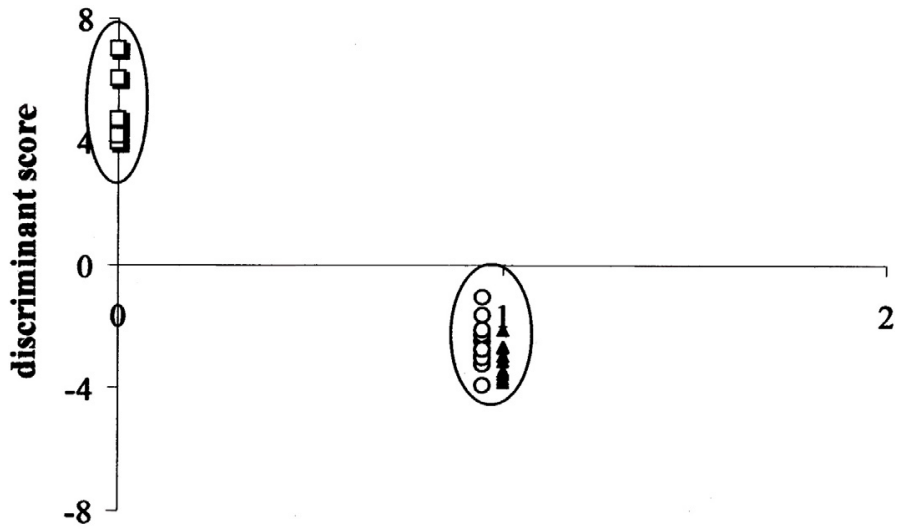

group value

Figure 2. Plot of the values of the discriminant scores (Discriminant Analysis) for workers (= hollow circles) and queens (= hollow squares). Large ellipsoids show the two groups. Males (= filled triangles) were treated as ungrouped cases. All 10 ungrouped data points (male samples) were assigned to the "worker group" and not to the "queen group". (To give a clearer picture the group value for the workers was lowered to 0.95 , whilst the original data give it as 1.0 as for the males).

Table II. Composition of the cuticular wax on the wings of individual males, workers, and queens of Melipona scutellaris together with the standard deviations of the samples. Bold numbers indicate major components. Except for the ethyl esters (E1 and E2), components representing less than $0.5 \%$ of the total have been excluded.

\begin{tabular}{lcccc}
\hline & & \multicolumn{3}{c}{ Mean amount $[\%] \pm$ s. d. } \\
\cline { 3 - 5 } Number in Figure 1 & Compound & $\begin{array}{c}\text { Males } \\
(n=10)\end{array}$ & $\begin{array}{c}\text { Workers } \\
(n=10)\end{array}$ & $\begin{array}{c}\text { Queens } \\
(n=5)\end{array}$ \\
\hline 1 & Nonadecane & 0 & 0 & $1.78 \pm 1.37$ \\
2 & Heneicosene & 0 & 0 & $0.99 \pm 0.98$ \\
3 & Heneicosane & 0 & $0.61 \pm 0.40$ & $1.18 \pm 1.15$ \\
E1 & Ethyl linoleate & $0.009 \pm 0.027$ & 0 & 0 \\
E2 & Ethyl oleate & $0.32 \pm 0.55$ & 0 & $1.70 \pm 2.00$ \\
4 & Docosane & 0 & $0.60 \pm 0.44$ & $0.99 \pm 0.39$ \\
5 & Tricosane & $1.26 \pm 0.24$ & $3.48 \pm 0.93$ & $\mathbf{3 7 . 5 0} \pm 8.26$ \\
6 & Tetracosane & 0 & $0.99 \pm 0.51$ & 0 \\
7 & Pentacosene & $2.51 \pm 0.71$ & $5.92 \pm 7.34$ & $6.96 \pm 1.39$ \\
8 & Pentacosane & $\mathbf{1 6 . 9 7} \pm 3.84$ & $\mathbf{2 1 . 6 6} \pm 9.08$ & $\mathbf{1 4 . 0 6} \pm 3.32$ \\
9 & Hexacosane & 0 & $2.40 \pm 2.08$ & 0 \\
10 & Heptacosene & $\mathbf{2 1 . 0 8} \pm 3.40$ & $\mathbf{2 3 . 7 2} \pm 10.06$ & $4.81 \pm 0.77$ \\
11 & Heptacosane & $\mathbf{2 4 . 3 5} \pm 3.40$ & $\mathbf{2 3 . 2 6} \pm 8.15$ & $5.28 \pm 1.63$ \\
12 & Nonacosene & $11.61 \pm 2.66$ & $6.85 \pm 2.07$ & $2.29 \pm 0.92$ \\
13 & Nonacosane & $8.36 \pm 2.04$ & $4.43 \pm 1.46$ & $1.44 \pm 0.48$ \\
A1 & Stearyl acetate & 0 & 0 & $11.58 \pm 8.70$ \\
A2 & Arachidyl acetate & 0 & 0 & $2.86 \pm 1.60$ \\
\hline
\end{tabular}


emerged queens and workers were tricosane and heptacosane, while that of newly emerged drones were nonacosane and methylnonacosane.

There are two modes of caste determination in eusocial bees (Kerr, 1950; 1975; Rachinsky et al., 1990; Hartfelder and Rembold, 1991; Kerr, 1997). In Apinae the development of the queen and workers depends on the quantity of food delivered. Different food intake affects activities of the corpora allata and the prothoracic glands, which provide different amounts of preimaginal juvenile hormone and ecdysteroids in workers and queens. But the different amounts of preimaginal juvenile hormone seemingly have no obvious influence on morphology and cuticular wax biosynthesis in the Apinae, suggesting other regulatory compounds or mechanisms in Apinae in contrast to meliponinine bees (Kerr, 1975; Evans and Wheeler, 1999). Consequently Apis workers are more similar to queens and different from males. This polyphenism not only includes morphological, but also physiological and behavioral differences (Weaver, 1966; Nijhout, 1994; Hartfelder and Engels, 1998).

In the Meliponinae a double heterozygous condition on two loci determines queen development and therefore caste determination (Kerr, 1950, 1987; Velthuis and Sommeijer, 1991). Yet, also, in meliponines, the endocrine system affects caste development, indicating that juvenile hormone became, through many evolutionary steps, gradually more important in expressing femaleness genes in queens, making queens become more different from workers. In line with this argument, workers would also become phenotypically more similar to males (Bonetti and Kerr, 1985; Bonetti et al., 1994; Kerr, 1997).

The present results show for the first time, that in the meliponine bee M. scutellaris the cuticular wax pattern is similar between males and workers, which adds additional chemical evidence to the morphological and behavioral data that workers are more similar to males than to queens in Meliponinae.

\section{ACKNOWLEDGEMENTS}

We acknowledge grants to WEK from the Brazilian National Research Council (CNPq), the State of Minas Gerais State Foundation (FAPEMIG) and SUFRAMA. HJ thanks the European Commission for the award of a TMR fellowship in the Network "Social Evolution". We thank Prof. C.D. Michener and Dra. G.A. Carvalho for reading the first draft and presenting suggestions.

Résumé - Les ouvrières de l'abeille sans aiguillon Melipona scutellaris sont plus proches des mâles que des reines par leurs composés cuticulaires. Chez les abeilles sans aiguillon (Apidae : Meliponinae), les mâles sont relativement semblables aux femelles, non seulement sur le plan morphologique mais aussi sur le plan comportemental (comportement de butinage semblable, production et travail de la cire, soin au couvain, trophallaxie, etc.). La présente étude montre qu'il y a chez Melipona scutellaris Latreille non seulement des ressemblances morphologiques et comportementales, mais que le profil des cires cuticulaires, analysé par chromatographie en phase gazeuse/spectrométrie de masse, est semblable chez les ouvrières et chez les mâles, alors qu'il diffère totalement entre mâles et reines et entre ouvrières et reines. L'heptacosane et l'heptacosène sont les composés majoritaires chez les mâles mais aussi chez les ouvrières, alors qu'ils sont minoritaires chez les reines où le composé majoritaire est le tricosane (Tab. II, Fig. 1). En outre différents composés acétates ont pu être identifiés chez les reines mais étaient totalement absents chez les mâles et les ouvrières. L'étude montre pour la première fois qu'à côté des structures morphologiques et des caractéristiques comportementales, il existe aussi des différences dans les voies de la biosynthèse des composés des cires cuticulaires, qui sont utilisées comme signaux de reconnaissance par les insectes. Nous suggérons que des mécanismes semblables d'expression et de régulation des gènes pourraient être à la base de la ressemblance observée dans la composition des hydrocarbures cuticulaires des ouvrières et des mâles de $M$. scutellari, tandis que des voies de biosynthèse différentes semblent être mises en jeu chez les reines.

Meliponinae / polyphénisme / différenciation castes / hydrocarbure / cuticule / signature chimique

Zusammenfassung - Arbeiterinnen der stachellosen Biene Melipona scutellaris sind in ihren cuticulären Substanzen eher männchen- als königinnenähnlich. Die Männchen stachelloser Bienen (Apidae: Meliponinae) sind nicht nur aufgrund morphologischer Befunde sondern auch von Verhaltensdaten her den Weibchen relativ ähnlich. Die vorliegende Untersuchung zeigt, dass ausser der Ähnlichkeit in Morphologie und Verhalten auch die Muster der Oberflächenwachse zwischen Arbeiterinnen und Männchen recht ähnlich sind, während sie sich zwischen Männchen und Königinnen einerseits und 
Königinnen und Arbeiterinnen andererseits deutlich unterscheiden. Heptacosan und Heptacosen sind die Hauptsubstanzen nicht nur bei Männchen sondern auch bei Arbeiterinnen, während bei Königinnen Tricosan die Hauptkomponente ist und Heptacosan und Heptacosen als Nebenkomponenten vorkommen (Tab. II, Abb. 1). Zusätzlich konnten nur bei Königinnen einige Acetatverbindungen gefunden werden, die bei Arbeiterinnen und Männchen völlig fehlten. Die vorliegende Untersuchungen zeigt zum ersten Mal, dass ausser morphologischen Strukturen und Verhaltensmerkmalen auch Unterschiede in der Zusammensetzung der Oberflächenwachse vorhanden sind, die bei Insekten insbesondere als Erkennungssignale genutzt werden können. Wir schlagen vor, dass der bei Melipona scutellaris beobachteten Ähnlichkeit in den cuticulären Kohlenwasserstoffen von Arbeiterinnen und Männchen ähnliche Genexpressionsmuster und regulatorische Mechanismen zugrunde liegen könnten, während bei Königinnen unterschiedliche Biosynthesewege eingeschaltet zu werden scheinen.

\section{Meliponinae / Polyphenismus / cuticuläreWasser-} kohlenstoffe / Kaste / chemische Unterschrift

\section{REFERENCES}

Almeida M.G. (1985) Sex determination in bees XXII. Generalized Malahanobis distances between males and females of the stingless bee Melipona scutellaris Latreille 1811, Rev. Bras. Genet. 8, 603-608.

Blomquist G.J., Tilman J.A., Mpuru S., Seybold S.J. (1998) The cuticle and cuticular hydrocarbons of insects: structure, function, and biochemistry, in: Pheromone Communication in Social Insects, Vander Meer R.K., Breed M.D., Winston M.L., Espelie K.E. (Eds.), Westview Press, Boulder and Oxford, pp. 34-54.

Boomsma J.J., Nielsen J., Sundström L., Oldham N.J., Tentschert J., Petersen H.C., Morgan E.D. (2003) Informational constraints on optimal sex allocation in ants, Proc. Natl. Acad. Sci. (USA) 100, 8799-8804.

Bonetti A.M., Kerr W.E. (1985) Sex determination in bees. XX. Study of Gene Action in Melipona marginata and Melipona compressipes Based on Morphometric Analysis, Rev. Bras. Genet. 8, 629638 .

Bonetti A.M., Cruz-Landim C., Kerr W.E. (1994) Sex determination in bees. XXX. Effects of juvenile hormone on the development of tergal glands in Melipona, J. Apic. Res. 33, 11-14.

Breed M. (1998) Chemical cues in kin recognition: criteria for identification, experimental approaches, and the honeybee as an example, in: Vander Meer R.K., Breed M.D., Winston M.L., Espelie K.E. (Eds.), Pheromone Communication in Social
Insects, Westview Press, Boulder and Oxford, pp. 57-78.

Campos L.A.O. (1975) Determinação de casta no gênero Melipona (Hymenoptera, Apidae), Papel do Hormônio Juvenil, Mestrado, FMRP - USP., 44 p.

Campos L.A.O. (1979) Determinação do sexo nas abelhas. XIII. Determinação das castas em Partamona cupira (Hymenoptera, Apoidea), Papel do hormônio juvenil, Ciênc. Cult. 31, 65-69.

Cruz-Landim C. (1963) Evolution of the wax and scent glands in the Apinae (Hymenoptera, Apidae), J. N.Y. Entomol. Soc. 7, 2-13.

Darchen R. (1969) Biology of Trigona and Melipona, Année Biol. 8, 455-490.

Drory E. (1874) Arbeit über Meliponiden, Bienenzeitung 30, 281-286.

Drory E. (1877) Les mélipones et les trigones, Rucher J. Apic. Rationnelle 5, 144-149.

Drory E. (1883) Nouvelles observations sur les mélipones, Le Rucher du Sud-Ouest 1, 59-61.

Evans J.D., Wheeler D.E. (1999) Differential gene expression between developing queens and workers in the honey bee, Apis mellifera, Proc. Natl. Acad. Sci. (USA) 96, 5575-5580.

Francis B.R., Blanton W.E., Littlefield J.L., Nunamaker R.A. (1989) Hydrocarbons of the cuticle and hemolymph of the adult honey bee (Hymenoptera: Apidae), Ann. Entomol. Soc. Am. 82, 486-494.

Hartfelder K., Rembold H. (1991) Caste-specific modulation of juvenile hormone III content and ecdysteroid titer in postembryonic development of the stingless bee, Scaptotrigona postica depilis, J. Comp. Physiol. B - Biochem. Syst. Environ. Physiol. $160,617-620$

Hartfelder K., Engels W. (1998) Social insect polymorphism: hormonal regulation of plasticity in development and reproduction in the honeybee, Curr. Top. Dev. Biol. 40, 45-77.

Kerr W.E. (1950) Genetic determination of castes in the genus Melipona, Genetics 35, 143-152.

Kerr W.E. (1974) Sex determination in bees, III, Caste determination and genetic control in Melipona, Insectes Soc. 21, 357-368.

Kerr W.E. (1975) Sex detemination in bees, III, Caste determination in Melipona and genetic control, Insectes Soc. 21, 357-368.

Kerr W.E. (1987) Sex determination in bees, XVII, Systems of caste in the Apinae, Meliponinae and Bombinae and their phylogenetical implications, Rev. Bras. Genet. 10, 685-694.

Kerr W.E. (1997) Sex determination in bees (Apinae, Meliponinae) and its consequences, Braz. J. Genet. 20, 601-612. 
Kerr W.E., Cunha R.A. (1990) Sex determination in bees, XXVI masculinism of workers in the Apidae, Rev. Bras. Genet. 13, 479-489.

Kerr W.E., Akahira Y., Camargo C.A. (1975) Sex determination in bees, IV, Genetic control of juvenile hormone production in Melipona quadrifasciata (Apidae), Genetics 81, 749-756.

Kerr W.E., Cunha R., Pisani J.F. (1978) Genetica da determinação do sexo em abelhas, XII, Aplicação de methodos numéricos para agrupar sexo e castas de Melipona quadrifasciata anthidioides Lep. (Apidae), Rev. Bras. Biol. 38, 391-394.

Monnin T., Peeters C. (1999) Dominance hierarchy and reproductive conflicts among subordinates in a monogynous queenless ant, Behav. Ecol. 10, 323-332.

Morgan E.D. (1990) Preparation of small scale samples from insects for chromatography, Anal. Chim. Acta 236, 227-235.

Morgan E.D., Wadhams L.J. (1972) Gas chromatography of volatile compounds in small samples of biological materials, J. Chromatogr. Sci. 10, 528529.

Nijhout H.F. (1994) Insect Hormones, Princeton Univ. Press, Princeton, N.J.

Oldham N.J., Morgan E.D., Billen J. (1994) On the similarity of the Dufour gland secretion and the cuticular hydrocarbons of some bumblebees, Physiol. Entomol. 19, 115-123.

Rachinsky A., Strambi C., Strambi A., Hartfelder K. (1990) Caste and metamorphosis - hemolymph titers of juvenile hormone and ecdysteroids in last instar honeybee larvae, Gen. Comp. Endocrinol. 79, 31-38.

Salt G.H. (1929) A contribution to the ethology of the Meliponinae, Trans. Entomol. Soc. 77, 431-470.

Singer T.L. (1998) Role of hydrocarbons in the recognition system of insects, Am. Zool. 38, 394-405.

Sledge M.F., Dani F.R., Cervo R., Dapporto L., Turillazzi S. (2001) Recognition of social parasites as nest-mates: adoption of colony-specific host cuticular odours by the paper wasp parasite Polistes sulcifer, Proc. R. Soc. London B-Biol. Sci. 268, 2253-2260.

Toth E., Strassmann J.E., Nogueira-Neto P., ImperatrizFonseca V.L., Queller D.C. (2002) Male production in stingless bees: variable outcomes of queenworker conflicts, Mol. Ecol. 11, 2661-2667.

Velthuis H.H.W., Sommeijer M.J. (1991) Roles of morphogenetic hormones in caste polymorphism in stingless bees, in: Gupta A.P. (Ed.), Morphogenetic Hormones in Arthropods: Roles in Histogenesis, Organogenesis and Morphogenesis, Rutgers Univ. Press, New Brunswick, New Jersey, USA, pp. 346-383.

Weaver N. (1966) Physiology of caste determination, Annu. Rev. Entomol. 11, 79-102.

Winston M.L., Michener C.D. (1977) Dual origin of highly social behavior among bees, Proc. Natl. Acad. Sci. (USA) 74, 1135-1137.

Zillig C. (1997) Dear Mr. Darwin (Data on the letters exchanged between Fritz Muller and Charles Darwin, in Portuguese), Sky Anima, Blumenau, Brasil. 